\title{
Zabit, nie zabił i kto kogo zabit? O filmie Zabicie ciotki Grzegorza Królikiewicza
}

Images

vol. XXX/no. 39

Poznań 2021

ISSN 1731-45OX

\begin{abstract}
Aвstract. Dondzik Michał, Zabit, nie zabit i kto kogo zabił? O filmie Zabicie ciotki Grzegorza Królikiewicza [Killed, not killed and who killed whom? On the film Killing Auntie by Grzegorz Królikiewicz]. "Images” vol. XXX, no. 39. Poznań 2021. Adam Mickiewicz University Press. Pp. 119-137. ISSN 1731-450X. DOI 10.14746/i.2021.39.06.

The subject of this article is an analysis of the film Killing Auntie (Zabicie ciotki, 1984) by Grzegorz Królikiewicz. The author reconstructs the history of the film's making, recalls the memories of actor Robert Herubin, cinematographer Krzysztof Ptak, and director Grzegorz Królikiewicz. The author reads Killing Auntie through the prism of Andrzej Bursa's prose, refers to the heritage of surrealism and the way the director refers to it. According to the author it is important to answer the question of whether Killing Auntie is a specific kind of performance. The article concludes with a reflection on the moral dimension of Killing Auntie and an attempt to answer the questions: did the murder in Killing Auntie really happen and could any of us commit it?
\end{abstract}

KeYworDs: Andrzej Bursa, Zabicie ciotki, Grzegorz Królikiewicz, Robert Herubin, Krzysztof Ptak, performans, surrealizm

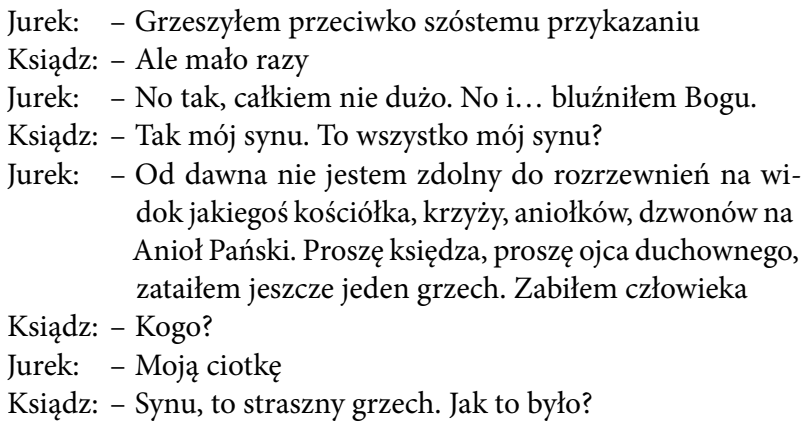

Zabicie ciotki

Kim był Andrzej Bursa, którego utwór zainteresował Grzegorza Królikiewicza na tyle, aby poświęcić mu szósty film fabularny? Janusz Roszko, urodzony tak jak Bursa w 1932 roku, napisał: „Mnie podobała się owa nuta ironiczna, sarkastyczna - ten dystans do współczesnego świata, jaki miał już wówczas, w wieku dwudziestu paru lat. Nikt z naszego pokolenia nie potrafił tak trafnie, gorzko i z taką znajomością życia pisać jak Andrzej, nikt nie potrafił wytworzyć w sobie takiego dystansu do otaczającego świata jak on" [1]. Z kolei Jerzy Kwiatkowski podkreślał: „[...] Bursa rozwijał się nadzwyczaj szybko: z gorączkową 
niecierpliwością. Wizjoner śmiały i sugestywny, choć nie zawsze zdolny opanować własną wyobraźnię - jako jeden z pierwszych osiągnął próg nadrealistycznej wrażliwości estetycznej... Poeta o wrażliwości nadzwyczaj wysublimowanej [...]"[2]. Zwieńczeniem literackiej drogi Andrzeja Bursy była nieukończona i nieopublikowana za życia twórcy mikropowieść Zabicie ciotki, w której zawarł szereg zagadnień znanych z jego utworów poetyckich. Maciej Chrzanowski napisał: „Problem martwej perspektywy młodości - jeden z podstawowo ważnych tematów

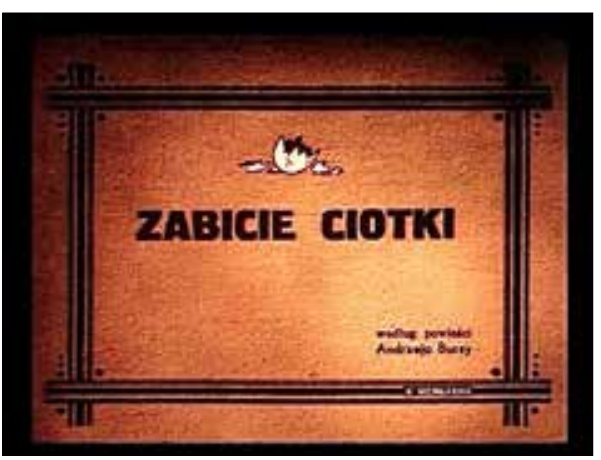

Il. 1. Czołówka filmu $Z a$ bicie ciotki, reż. Grzegorz Królikiewicz całej twórczości Andrzeja Bursy, motyw pojawiający się w licznych jego wierszach i w niektórych opowiadaniach - w Zabiciu ciotki znajduje swą kulminację, zostaje najpełniej i najciekawiej rozwinięty"[3].

Śmierć poety oraz buntowniczy, nonkonformistyczny charakter jego twórczości stał się zaczynem do powstania legendy Bursy. „Nie tylko został obwołany idolem kontestującej młodzieży, przez krytykę zaś obdarzony znaczącymi określeniami «poeta przeklęty», «kamikadze», «kaskader», "polski James Dean itp.»"[4].

Grzegorz Królikiewicz szukając materiału literackiego na film fabularny, myślał między innymi o adaptacji opowiadania And Stanisława Czycza, utworu będącego impresją o życiu Andrzeja Bursy. „To co mnie fascynowało w Andzie, to sprawa, do czego prowadzi nadużycie wyobraźni. Przecież to, co opowiada w Andzie narrator o swoim przyjacielu i o sobie, jest stworzeniem tak niesamowicie niebezpiecznej sytuacji życiowej, iż w końcu prowadzi ona do unicestwienia"[5] - wyjaśniał reżyser.

Ostatecznie Królikiewicz zdecydował się na ekranizację $\mathrm{Za}$ bicia ciotki. Film oparty na utworze Andrzeja Bursy, podobnie jak wcześniej Na wylot i Fort 13, powstał dzięki inspiracji. „Pani doktor Bronisława Stolarska - wspominał reżyser - powiedziała: «koniecznie musisz przeczytać tę książkę - to jest rzecz dla ciebie», [...] zacząłem ją wnikliwie penetrować i myślę sobie, co ta pani miała na myśli, tak mnie namawiając?"[6].

W grudniu 1981 roku, za kwotę 25000 zł, spadkobiercy Andrzeja Bursy (Michał i Ludwika Bursa) sprzedali Zespołowi Filmowemu Aneks, reprezentowanemu przez Grzegorza Królikiewicza (kierownika

[2] J. Kwiatkowski, Poezja Andrzeja Bursy, „Przegląd Kulturalny" 1959, nr 19, s. 5.

[3] M. Chrzanowski, Andrzej Bursa. Czas, twórczość, mit, Kraków 1986, s. 127-128.

[4] E. Dunaj Kozakow, Bursa, Kraków 1996, s. 6.

[5] B. Stolarska, Twórczość filmowa Grzegorza Królikiewicza. Sesja filmoznawcza, 13-16 maja 1987, Łódzki Dom Kultury - DKF 1987, s. 8.

[6] Spotkanie z Grzegorzem Królikiewiczem w Muzeum Sztuki Nowoczesnej w Łodzi, 3 czerwca 2011,
Archiwum Michała Dondzika [dalej: AMD]. Bronisława Stolarska zapamiętała ten moment następująco: „Królikiewicz chciał realizować film na podstawie innej książki, a ja mu mówię: a może Zabicie ciotki? Przeczytał i uznał, że to jest jego temat. Zabicie ciotki to powieść niezamknięta, nieskończona, można było w nią wiele rzeczy wpisać, co też reżyser zrobił”. Rozmowa Michała Dondzika z Bronisławą Stolarską, 10 maja 2016, Łódź, AMD. 
artystycznego) oraz Jerzego Niteckiego (szefa produkcji zespołu), prawa do Zabicia ciotki. W ramach zawartej umowy syn oraz żona poety zgodzili się na ewentualne „przeróbki, przystosowania i uzupełnienia utworu innej osobie według uznania Przedsiębiorstwa”[7].

Scenariusz filmu na podstawie Zabicia ciotki Grzegorz Królikiewicz napisał wspólnie z Krzysztofem Skudzińskiem (kierownikiem literackim w Zespole Aneks). Efekt prac nie był w pełni zadowalający i o stworzenie kolejnej wersji Królikiewicz zwrócił się do reżysera Henryka Dederki. „Powiedział [Królikiewicz - M.D.], że materiał nie nadaje się do niczego, żebym napisał coś, co można wziąć na plan albo do zatwierdzenia" [8] - komentował Dederko. Prace nad adaptacją Zabicia ciotki wstrzymało odwołanie Grzegorza Królikiewicza z funkcji kierownika artystycznego Aneksu i późniejsze rozwiązanie zespołu. Nie wiadomo jak potoczyłyby się losy filmu, gdyby nie Wojciech Jerzy Has, który zdecydował się na jego realizację w kierowanym przez siebie Zespole Rondo. Scenariusz nie spotkał się z uznaniem oceniających go recenzentów i dopiero po interwencji u Jerzego Bajdora (wiceministra Kultury i Sztuki)[9] projekt filmu pod roboczym tytułem Ciotka skierowano do produkcji w grudniu 1983 roku[10].

Analizując Zabicie ciotki, nie sposób nie omówić związków filmu Grzegorza Królikiewicza z surrealizmem[11]. André Breton w Manifeście surrealizmu napisał: „Surrealizm opiera się na wierze w nadrzędną rzeczywistość pewnych form skojarzeniowych dotąd lekceważonych, we wszechpotęgę marzenia, w bezinteresowną grę myśli. Dąży do ostatecznego zniszczenia wszelkich innych mechanizmów psychologicznych i zajęcia ich miejsca w rozwiązywaniu podstawowych zagadnień życia”[12]. Prekursorem i niekwestionowanym twórcą surrealizmu w filmie jest Luis Buñuel, reżyser Psa andaluzyjskiego (1929) i Złotego wieku (1930). W obu tych modelowych dziełach surrealizmu istotną rolę odgrywały sny.

[7] Umowa o nabycie praw autorskich do napisanego utworu pt. „Zbiór opowiadań Zabicie ciotki”, 7 grudnia 1981 roku, Przedsiębiorstwo Realizacji Filmów Zespoły Filmowe, Z.F. Aneks. Umowy autorskie 1980-1983, sygn. 427, Archiwum Państwowe Dokumentacji Osobowej i Płacowej w Milanówku.

[8] Rozmowa Michała Dondzika z Henrykiem Dederką, 20 grudnia 2017, Łódź, AMD.

[9] Zob. Stenogram z posiedzenia Komisji Kolaudacyjnej Filmów Fabularnych w dniu 1 października 1984 roku. Na porządku dziennym omówienie filmu Zabicie ciotki zrealizowanego przez Grzegorza Królikiewicza, sygn. A-344, poz. 378, k. 12, Archiwum Filmoteki Narodowej - Instytutu Audiowizualnego [dalej: AFINA].

[10] Dokładnie 19 grudnia 1983 roku. Zob. szczegółowy plan filmu Ciotka. Dane ogólne filmu Ciotka, k. 1, sygn. S-24259, AFINA.
[11] Porównanie z surrealizmem wykorzystał do ataku na film Lucjan Kydryński: „W tym narracyjnym pogmatwaniu sporo obrzydliwości czysto wizualnych, epatowanie mocnymi scenami, jak gdyby rodem z surrealistycznych filmów sprzed sześćdziesięciu lat [...]". Aleksandra [Lucjan Kydryński], Zabicie ciotki i powolne umieranie ( $z$ nudów) publiczności..., „Przekrój" 1985, nr 105, s. 22. Z kolei Maria Malatyńska napisała: „I jakkolwiek otrzymaliśmy film jakby nieco «przyciężki» i jakby zbyt konkretny w swoim przecież surrealizmie [...]. M. Malatyńska, Bursa i Królikiewicz, „Echo Krakowa” 1985, nr 213, s. 2. Zdaniem Mirosława Winiarczyka „Film przypomina senne, surrealistyczne fantasmagorie". Zob. M. Winiarczyk, Na co do kina - „Zabicie z ciotki”, „Ekran” 1985, nr 37, s. 17.

[12] A. Breton, Manifest surrealizmu, [w:] Surrealizm. Teoria i praktyka. Antologia, teksty wybrał i przełożył A. Ważyk, Warszawa 1976, s. 77. 
Jednak Grzegorz Królikiewicz nie był zachwycony wpisywaniem Zabicia ciotki w poetykę surrealizmu: „Jak w matrycy, powtarza się ten rodzaj pomyłki i pomówienia. [...] Owszem wiadomo, że ten utwór jest "przylepiony» jako replika. To jest rozważanie o hamulcu dla tego typu wolności wewnętrznej, jaką uwielbia surrealizm”[13]. W dalszej części wywodu tłumaczył: „Surrealiści bardzo dokładnie oddzielili to co realne od tego, co jest z głębi podświadomości i nadawali temu, co z głębi podświadomości kształt, powiedziałbym, znobilitowany, kształt, który formułowała funkcja poetycka: rozgraniczenie realności i nadrealności. W filmie Zabicie ciotki sama podświadomość i wewnętrzna gra intencji zostaje niejako skompromitowana, bo w moim filmie przynależy ona do rzeczywistości filmowej, ona się «myli» z rzeczywistością fizyczną i już w sferze stylu następuje osąd"[14]. Po latach od premiery filmu dodał: „Mój surrealizm w Zabiciu ciotki był perwersyjny. Surrealiści robili wszystko, żeby odróżnić jawę od snu, zdegradować

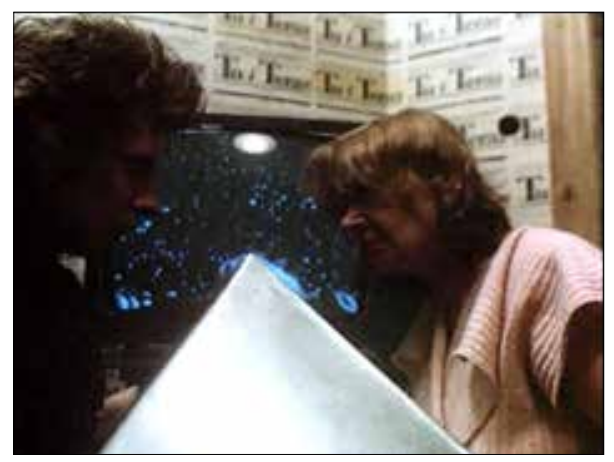

Il. 2. Jurek (Robert Herubin) i ukochana ciotka (Maria Klejdysz) rzeczywistość kosztem snu. Mnie natomiast chodzi o osiągnięcie maksymalnego ujednolicenia" [15].

W Zabiciu ciotki nie znajdziemy niezwykłych surrealistycznych elementów, zaczerpniętych wprost z poetyki snu, można jednak wskazać momenty, w których rzeczywistość psychiczna staje się realnością. Spiker z telewizji spoglądający na bohatera i przemawiając do niego pojawia się w realnym świecie, obserwując młodzieńca na poczcie, kiedy ten wysyła paczkę ze zwłokami ciotki (Maria Klejdysz). Scena, gdy Jurek (Robert Herubin) jedzie karawanem pogrzebowym, wykrzykując: „Sam uprawię swoje poletko. A piłką, siekierą! Morduję! Morduję! Jak mawiał stary Goethe..."[16], ma swoją kontynuację na komisariacie. Jeden $\mathrm{z}$ obecnych

[13] B. Stolarska, op.cit., s. 8.

[14] Ibidem, s. 9.

[15] Przekształcić cierpienie w wartość - z Grzegorzem Królikiewiczem rozmawiał Tadeusz Sobolewski, „Kino” 1993, nr 12, s. 13. Po latach w wywiadzie rzece Królikiewicz przyznał: „Ten film jest moją wariacją na temat surrealizmu, który wyłania się i zanika bez jakichś wyraźnych granic. Nie ma granicy między marzeniem sennym a rzeczywistością. Nam się wydaje, że ta granica istnieje, rysujemy ją w umyśle, w świadomości, która - paradoksalnie - wyłania się z nieświadomości. Zależało mi, żeby to płynnie przeniknąć jedno w drugie, bo dopiero wtedy zaczyna się zmora naszej dezorientacji w świecie". Królikiewicz. Pracuję dla przyszłości: wywiad rzeka, rozm. P. Marecki, P. Kletowski, Kraków 2011, s. 222.

[16] W książce Andrzej Bursa opisał tę scenę następująco: „Ja sam uprawię moje krwawe poletko. A piłą, a siekierą! Morduję... morduję... Karawan oddalał się w ciągłym szumie kół i stukocie kopyt. Popatrzyłem za nim i powiedziałem głucho: - Jak powiedział stary Goethe, jak powiedział stary Goethe.... A. Bursa, Zabicie ciotki, Kraków 1981, s. 47. W scenie z karawanem jako woźnicę zatrudniono Jana Himilsbacha, ten jednak w dniu poprzedzającym nagranie wraz z Robertem Herubinem raczył się alkoholem i nie był w stanie uczestniczyć w zdjęciach. Dlatego też w scenie widać jedynie Jurka, a postać prowadząca konny karawan pozostaje poza kadrem. Rozmowa Michała Dondzika z Robertem Herubinem, Łódź, 1 grudnia 2017, AMD. Wspomnienie Roberta Herubina potwierdza zapis $\mathrm{w}$ dokumencie $\mathrm{z}$ produkcji filmu. Scena „Karawan” z udziałem Jana Himilsbacha miała się odbyć 27 kwietnia 1984 roku, obok aktora miał wystąpić w niej autentyczny karawaniarz. Zob. Perspektywka z dni 26 kwietnia - 15 maja 1984. Dokument w archiwum Alicji Wierzbickiej. 
na posterunku stróżów prawa podobny jest do autora Fausta, filmowy Johann Wolfgang Goethe, mimo przebrania w mundur milicjanta, to wcielenie poety z olejnego portretu pędzla Josepha Karla Stielera. Wypowiedziane w pijackim widzie słowa Jurka materializują się.

$\mathrm{W}$ jednym $\mathrm{z}$ ujęć Zabicia ciotki w tle widoczne są afisze $\mathrm{z}$ wystaw Zbigniewa Warpechowskiego Happeningi, akcje performances $z$ lat 1967-1981[17]. Wątek ten powraca w ostatniej scenie filmu - Luiza mówi do Jurka: „Coś ty tu wyrabiał? Co znaczą te pudełka w korytarzu aż pod sufit? Znów te twoje happeningi, te twoje performans... Zezwalam ci, ale zawsze cię proszę, zostaw chociaż po sobie porządek..."[18]. Pytanie zadane bohaterowi jest w rzeczywistości skierowane do widza. Czy historia, którą śledził, oglądając film, nie była performansem, czyli rodzajem wydarzenia, w którym główną rolę odgrywa artysta, będący zarówno twórcą, jak i tworzywem sztuki?

Definicja performansu jest dość migotliwa, a każdy z nowych „procederów artystycznych” może podważyć wcześniejsze znaczenia tego pojęcia[19]. Jak podkreślał Zbigniew Warpechowski: „Sztuka performance jest ostatnim etapem Sztuki $\mathrm{Nr}$ 1, najdalej wysuniętą konsekwencją doświadczeń artystycznych i wiedzy towarzyszącej wszystkim rodzajom sztuki. Jest nie tyle «uwieńczeniem» sztuki, ile raczej sublimacją istoty artystycznego powołania, i tym samym negacją wszelkich wybujałości, narosłych na drodze, po drodze, artystycznych uwikłań, uzależnień, sprzężeń, uległości, słabości, ustępstw, którymi żywi się świat sztuki zamiast sztuki”[20].

Na czym polega performans w Zabiciu ciotki? Grzegorz Królikiewicz wyjaśniał to następująco: „Ten młody człowiek, który okazuje się artystą, myśli sobie tak: skoro ja pomyślałem sobie, żeby ciocię rąbnąć młotkiem, to od tej pory traktuję to jako rzeczywistość, co prawda ciocia wyjechała na wczasy dwutygodniowe, ale ja przez ten cały czas wiem, że ciało cioci leży koło kuchenki, [...] że muszę ją teraz schować przed publicznością”[21]. Dodał: „Otóż Jurek jest szczególnego rodzaju performerem, który robi swoim kosztem, ze swoim udziałem, performans niespotykany, dlatego że on jest performerem i jednocześnie jednoosobową widownią"[22].

Podstawowym poziomem filmowego performansu w Zabiciu ciotki jest zatem sytuacja, w której bohater traktuje zbrodnię dokonaną w myślach jako fakt. Jurek inscenizuje własną wersję Zbrodni i kary, Dostojewski napisał powieść o zbrodniczym czynie, a tu tematem jest zbrodnicza myśl. W kontekście performansu tworzonego przez bohatera warto zwrócić uwagę na jego personalia. Na nadawanej paczce oraz

[17] Są to plakaty z dwóch wystaw, pierwsza odbyła się w Galerii Krzysztofory w Krakowie w grudniu 1981, druga w Biurze Wystaw Artystycznych w marcu 1982. [18] Cytat z filmu Zabicie ciotki.

[19] Z. Warpechowski, Konserwatyzm awangardowy, Kraków 2014, s. 150.
[20] Idem, Podnośnik, Jerozolima - Rzym - Sandomierz 2001, s. 54.

[21] Spotkanie z Grzegorzem Królikiewiczem, Muzeum Sztuki Nowoczesnej w Łodzi, 3 czerwca 2011, AMD.

[22] Rozmowa Bronisławy Stolarskiej z Grzegorzem Królikiewiczem, Łódź, czerwiec 2010, AMD. 
na uczelnianym indeksie widnieje imię i nazwisko[23]: Jerzy Robert Cherubin. Robert Franciszek Herubin to przecież aktor odgrywający rolę Jurka[24]. Herubin był także artystą, zajmował się malarstwem, ale i bardziej nowoczesnymi formami sztuki. „Być może pomysł na Jurka performera wziął się od mojej osoby, bo ja byłem wtedy performerem. Miałem w Warszawie kilka performansów, to się odbywało w prywatnej pracowni u pani Jarosińskiej, przychodzili tam tacy goście jak Henryk Stażewski"[25] - wyjaśniał.

Czy zatem Zabicie ciotki można traktować jako swoiście pojmowany filmowy performans[26]? Aby odpowiedzieć na to pytanie, trzeba zastanowić się, jak Królikiewicz kreuje filmową rzeczywistość. W Zabiciu ciotki nie pojawia się żadna postać zbudowana w opozycji do głównego bohatera. Widz skazany jest na utożsamienie się z przestępcą i jego próbami zatarcia śladów mordu. Królikiewicz, choć korzysta $\mathrm{z}$ fabularnych klisz kina gatunku, nie spełnia zasad „filmu stylu zerowego". Zabicie ciotki nie jest: jednoznaczne i zrozumiałe, realistyczne i obiektywne, ani przeźroczyste formalnie; to co łączy ten obraz z kinem gatunku to świadome oddziaływanie na emocje[27]. Grzegorz Królikiewicz aż do finału filmu steruje reakcjami widza, wykorzystując konwencję kina gatunków: bohater stara się ukryć swoją zbrodnię, czuje się osaczony, obawia się demaskacji i aresztowania. Twórca posługuje się też chwytami charakterystycznymi dla thrillera czy horroru, na przykład poprzez makijaż babci Jurka (Wanda Łuczycka), która swoim wyglądem przypomina „żywego trupa”[28], tudzież inne dosadne okropności - kanibalizm, karmienie drapieżników w ogrodzie zoologicznym ludzkim mięsem, dzielenie zwłok ciotki Luizy siekierą itp.

Wybijanie odbiorcy z poznawczych nawyków osiąga Królikiewicz na wiele sposób, na przykład za pomocą nieumotywowanej fabularnie animowanej wstawki (Jurek jadący na nartorolkach po wstędze Möbiusa). Istotne są też gry z czasem - sprzeczne informacje, zakłócenie chronologii, długość poszczególnych scen. Rytm narracji rozsadzają kontemplacyjne sceny dialogowe (trwająca ponad dziewięć minut spowiedź Jurka czy też równie długa scena wyznania Jurka przed Teresą). Większość wydarzeń rozgrywa się w ciasnej przestrzeni domu

[23] W indeksie widoczny jest też autentyczny podpis aktora Roberta Herubina.

[24] Jerzy to imię zaczerpnięte z powieści Andrzeja Bursy.

[25] „W jednym z performansów wymyśliłem sobie, że zabiję królika. Miałem siekierę, pokazywałem zdjęcia z Wietnamu, okrutności, straszne rzeczy, flaki. To rzeczywiście budziło w ludziach emocje. Aktor Eugeniusz Priwieziencew przyszedł na pokaz i tak się zbulwersował, że wyszedł z krzykiem. A ja tylko straszyłem". Rozmowa Michała Dondzika z Robertem Herubinem, 24 listopada 2017, AMD.
[26] W swojej pracy staram się zbadać, jak Królikiewicz kreuje swój filmowy performans; mniej interesuje mnie pojęcie performansu w innych tekstach kultury.

[27] M. Przylipiak, Kino stylu zerowego. Dwadzieścia lat później, Sopot 2016, s. 87-88.

[28] „Babkę sięgającą już osiemdziesiątki bolały ciągle oczy i smarowała je dokoła jaskrawobiałą maścią. Wyglądała przez to jak dziwaczny ptak. Patrząc na nią, myślałem zawsze, że jeżeli istnieje biblijne określenie «pobielany grób», to jest właśnie to". Zob. A. Bursa, op.cit., s. 71. 
bohatera - to tu następuje domniemane zabójstwo, tu Jurek usiłuje ukryć dowody „ciotkobójstwa”, tu z urlopu wraca Luiza.

Mimo że kamieniczne lokum obserwujemy przez dużą część filmu, zadaniem karkołomnym jest orientacja w jego przestrzeni. W filmie ukazana zostaje poćwiartowana jak zwłoki ciotki rzeczywistość łazienka, pokój Jurka, korytarz. Jaki dokładnie ma rozkład mieszkanie w łódzkiej kamiennicy - dociec trudno. Efekt dezorientacji uzyskany jest dzięki zdjęciom Krzysztofa Ptaka, który wiele scen kręci z nietypowych perspektyw, na przykład pionowe ujęcia ukazują rzeczywistość $\mathrm{z}$ perspektywy sufitu.

Zależało mi, żeby świat tego chłopaka, który przebywa w klaustrofobicznych pomieszczeniach, był organiczny, narzucający się. Chodziło o takie przekadrowania, żeby oddać wyobcowanie postaci [...]. Jest to świat wymyślony przez Bursę. Czy to się dzieję w głowie tego chłopaka? Zależało nam, aby granice między jawą a snem się zacierały, żeby widz był zdezorientowany, dlatego zostawialiśmy mylne tropy [29]

- wyjaśniał operator.

Planom zbyt bliskim, podkreślającym osaczenie bohatera (na przykład w scenie na poczcie Jurek nieomal wpada na kamerę, wypatrując śledzących go osób), towarzyszą ujęcia dezorientujące widza (na przykład w scenie spotkania z Dziką Dziewczyną [Jolanta Mielech] kadr zasłania przejeżdżający autobus, po chwili ukazane jest tylko zbliżenie gryzącej Jurka bohaterki). Nadmiernie bliskie plany współgrają z charakterystycznymi przekadrowaniami, niektóre ujęcia zostały sfilmowane $\mathrm{z}$ większą przestrzenią u góry kadru lub wokół bohaterów. Poprzez taki zabieg postacie na zdjęciach są niewielkimi elementami kadru i zyskują nad sobą dodatkową sferę (w scenie próby samobójczej to co ważne, Jurek i ratujący go pies, jest mniej widoczne niż to, co nieistotne - obecne na pierwszym planie doniczki z paprotkami PRL-owskim kwiatem dekoracyjnym). Świat w Zabiciu ciotki ukazany jest w sposób skrajnie subiektywny. Efekt ten wzmacnia zaczerpnięta z muzyki zasada ronda. „[...] Powracają różne rzeczy, pomarańczowe paczki, doświadczenia, powraca ciotka”[30] - wyjaśniał reżyser.

Wyrazistą manifestacją „zasady ronda” jest scena, w której wyrzucone do rzeki przez Jurka i Teresę (Mirosława Zaborowska) paczki ze zwłokami ciotki wbrew naturze nurt przywodzi na powrót do bohaterów. To, czego chcą się wyzbyć postacie, powraca do nich. Dotyczy to zarówno sfery fizycznej, jak i psychicznej. „Myśl o zbrodni toczy się w tobie jak koło i trwa w powtórzeniach" - mówi do Jurka w trakcie spowiedzi ksiądz (Józef Pieracki). Powracającymi motywami są przedmioty nawiązujące do morderstwa oraz jego potencjalnych konsekwencji. Jurka osaczają kraty: w trakcie spowiedzi na twarzy Jurka widoczny jest cień kraty konfesjonału, na tle krat pojawiają się postacie w transmisjach telewizyjnych, przez kraty bohater patrzy w twarz małpy,

[29] Rozmowa Michała Dondzika z Krzysztofem Ptakiem, Łódź, 4 czerwca 2016, AMD.
[30] Królikiewicz. Pracuję dla przyszłości: wywiad rzeka..., s. 223. 


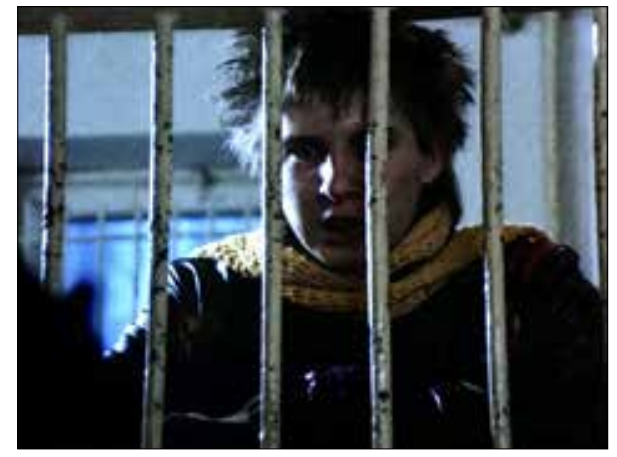

Il. 3. Kraty osaczaja Jurka (Robert Herubin)

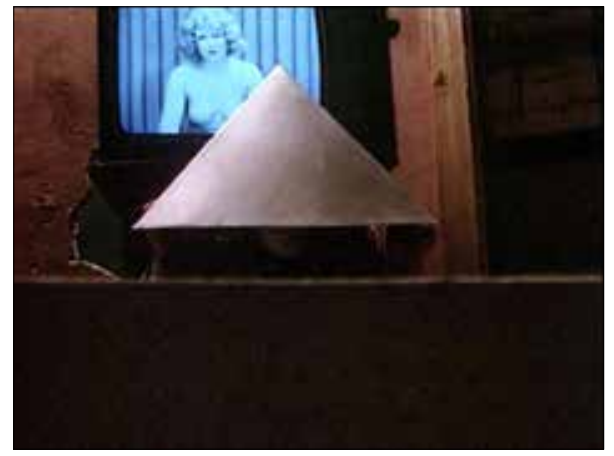

Il. 4. Piramida i naga prawda w peerelowskiej telewizji za kratami znajdują się drapieżniki w zoo. Bezpośrednimi aluzjami do więzienia, do którego może trafić bohater, są kraty na komisariacie i więziennej celi. Szczególnie ciekawe jest ujęcie, kiedy chłopak ukazany jest przez kraty w klatce kanarka. Czyż Jurek nie jest człowiekiem uwięzionym w klatce swojej wyobraźni? Czy jego mieszkanie nie pełni funkcji więzienia? Gdy przyglądamy się śpiewającemu kanarkowi, dostrzegamy pętlę, która zamocowana jest w górnej części klatki. Ten nietypowy element wyposażenia stanowić może zapowiedź potencjalnego losu Jurka.

Motyw pętli powróci, gdy bohater leży w wannie (pętlę tworzy wąż od prysznica), w scenie, w której Jurek panikuje, nie mogąc podołać podzieleniu zwłok ciotki. Stan osaczenia bohatera podkreśla pokazanie „ciotkobójcy” pomiędzy dwoma ściskającymi go skrzydłami drzwi. W pomieszczeniu obok widoczny jest katowski sznur z zawiązaną pętlą, jakby oczekujący na skazańca. Powracają też elementy bezpośrednio związane z morderstwem ciotki Luizy - młotek i krew. Ta ostatnia, niczym w przypadku Lady Makbet, prześladuje bohatera. $\mathrm{Na}$ nic zdają się próby spłukania krwawych śladów z ręki Jurka; krew jest niezbywalnym dowodem winy. Powtarza się też motyw bicia Jurka po twarzy: najpierw w ataku autoagresji robi to sam bohater, a następnie Teresa. Przywołując przykłady powtórzeń, nie sposób nie wspomnieć o pojawiających się w filmie ciotkach. Pierwszą z nich jest tytułowa Luiza, która powraca w finale filmu, druga ciotka to Emilka (Krystyna Feldman), która wraz z babcią odwiedza Jurka. Jednak najbardziej enigmatyczną postacią jest ciotka, wzywająca Teresę z balkonu. „Do jakiego zakonu ty należysz?” - pyta bohater. Trzecia z filmowych ciotek jest jakoby zakonnicą, mającą na dziewczynę większy wpływ niż jej matka.

Najbardziej tajemniczym z powracających w Zabiciu ciotki motywów są piramidy. To symetrycznie ustawione błyszczące ostrosłupy mijają w lesie Jurek z Teresą w drodze nad rzekę. Bohaterowie nie zwracają uwagi na ten niecodzienny element, jakby był dla nich niewidoczny lub niewart zainteresowania. Egzemplarz piramidy ma u siebie w mieszkaniu Jurek. Model z zaznaczonymi kolorowo strefami (czerwoną, żółtą i zieloną) wisi w pokoju bohatera. Przez pewien czas chłopak trzyma we wnętrzu piramidy głowę, by następnie zapakować ostrosłup do paczki z peruką - domniemanym skalpem zdartym $\mathrm{z}$ ciotki. W końcówce filmu paczkę tę odbiera ciotka Luiza, jednak w środku, w miejscu gdzie znajdowała się peruka, widoczny jest ozdobny młotek. Czyżby moc piramidy spowodowała tę niezwykłą transmutację?

Obecne w Zabiciu ciotki nawiązania do energii wykorzystywanych przez faraonów i starożytnych Egipcjan są ewokacją zagadnień frapujących wówczas Grzegorza Królikiewicza. Reżyser 
posiadał niewielki „domowy” model piramidy, zbudował także większą piramidę w ogródku. Odbywały się tam spotkania i narady z filmowymi współpracownikami[31].

Jak pisaliśmy scenopis - wspominał operator Krzysztof Ptak - poszedłem do pracowni Grzegorza. Wisiała tam na sztycy piramida. Grzesiek poprosił, żebym pod nią usiadł, bo będę miał lepsze pomysły. Dał mi drucik do trzymania $w$ ręku, który był połączony $\mathrm{z}$ tą piramidą. Coś tam czułem, nie wiem czy kuracja podziałała, ale pomysły były dobre[32].

Działanie piramidy reżyser testował także w trakcie prowadzonych przez siebie zajęć. Na ich potrzebę w sali synchronizacyjnej Wydziału Dźwięku Wytwórni Filmów Fabularnych w Łodzi studenci Szkoły Filmowej przy pomocy pracowników wytwórni zbudowali replikę piramidy Cheopsa, wewnątrz której odbywały się prowadzone przez Grzegorza Królikiewicza zajęcia[33]. W ich trakcie reżyser wyjaśnił, na czym polega oddziaływanie piramidy:

Dla niektórych energia [piramidy - M.D.] może być czymś pozytywnym, ale dla innych, już naładowanych tego typu energią, może spowodować nadmiar i mogą powstać u nich ujemne objawy fizjologiczne i psychologiczne, mogą się pojawić mrowienia w kończynach, na karku. W pojemności czaszki możemy odczuć, że wzrosła zawartość płynu w mózgu; jak gdyby się lekko nie mieścił w czaszce. Odczuwać możemy też stan dziwnego rozjaśnienia świadomości w połączeniu $\mathrm{z}$ wrażeniem jej zawężenia. [...] Poza tym pojawić się może takie wrażenie, jak: widzenie składu molekularnego powietrza, wrażenie innego upływu czasu[34].

Piramida to konstrukcja w kształcie ostrosłupa prawidłowego, jej ściany składają się z trójkątów. W przeciwieństwie do piramid, których repliki pojawiają się filmie, trójkąty tworzone są poprzez zakrycie części filmowego kadru. Zabieg jest w warstwie obrazu powtarzany kilkukrotnie - w finałowej scenie, poprzez zasłonięcie części telewizora piramidą, powstaje trójkąt ukazany na tle kosmosu, w scenie powrotu ciotki zaś figura pojawia się w lewym górnym rogu kadru dzięki zasłonięciu tej części parasolką Luizy, która też składa się z błyszczących trójkątów.

Zasada ronda, wedle której w Zabiciu ciotki powracają przedmioty zarówno bezpośrednio nawiązujące do zbrodni Jurka, dotyczy i tych, które są emanacją tajemniczych sił i potęgi ludzkiej myśli. Przypomnijmy, że w intencji reżysera cały film to performans Jurka, robiony dla jednego widza, którym jest sam bohater. „Otóż ten performans, tak ułożony, w taki wirujący trójkąt stał się zaczynem formalnym tego

[31] Rozmowa Michała Dondzika z Jerzym Borowiczem, 13 grudnia 2017, AMD.

[32] Rozmowa Michała Dondzika z Krzysztofem Ptakiem, 4 czerwca 2016, Łódź, AMD.

[33] Ksiega Godarda. Spotkanie seminaryjne z cyklu: Co po Godardzie? pt. W piramidzie. Protokół zajęć "Analiza dzieła filmowego" prowadzonych na Wydziale Reżyserii Filmowej i Telewizyjnej PWSFTviT w semestrze letnim 1984/1985 pod kierunkiem Grzegorza Królikiewicza, red. A. Wierzbicka, E. Ostrowska, s. 7.

[34] Osoby zainteresowane zagadnieniem piramid w twórczości Grzegorza Królikiewicza odsyłam do: Ksiega Godarda. Spotkanie seminaryjne z cyklu: Co po Godardzie? pt. W piramidzie..., s. 9. 
filmu"[35] - wyjaśniał Grzegorz Królikiewicz. Zatem o performansie w Zabiciu ciotki można mówić przynajmniej w trzech aspektach. Pierwszym i najbardziej oczywistym jest performans odgrywany przez Jurka, fikcyjną postać ze świata filmu. O tym, że chłopak para się tego typu działalnością, dowiadujemy się od ciotki. Przedmiotami stanowiącymi elementy artystycznego występu są powracające w filmie paczki i piramidy. Drugi poziom performansu tworzy fakt przenikania się postaci Jurka z grającym go aktorem (zbieżne personalia, Robert Herubin przed podjęciem roli w Zabiciu ciotki zajmował się performansem) oraz reżyserem filmu. Warto odnotować, że część z ukazanych w filmie wydarzeń znaleźć można w biografii Grzegorza Królikiewicza. Zapytany w 2017 roku o swoje powinowactwo z filmowym Jurkiem, artysta zaprzeczył, podkreślając, że najważniejsze były dla niego lektury[36]. Przypomnijmy jednak, że przed zdaniem na reżyserię Królikiewicz studiował (tak samo jak bohater filmu) na Wydziale Prawa Uniwersytetu Łódzkiego. To jemu przytrafiła się historia (ukazana w Zabiciu ciotki) wyrzucania w trakcie zajęć przez okno studenckiego indeksu przez profesora [37]. Co więcej, podczas studiów, pochodzący z Piotrkowa Trybunalskiego, artysta mieszkał u swojej matki chrzestnej, ciotki Ali (Alicja Giercuszkiewicz), w łódzkiej kamienicy przy ulicy Piotrkowskiej 73. Zainspirowana autentycznym doświadczeniem jest też scena, kiedy ciotka wpada na pomysł uprania bielizny, którą Jurek ma na sobie. „Była wspaniała [ciotka Ala - M.D.], ale nie znosiłem, kiedy była nadopiekuńcza, wręcz bezwstydna w swojej miłości i trosce o zdrowie naszej wielkiej rodziny. I to znalazło się w moim Bursie"[38] - podkreślał filmowiec. Królikiewicz performans wykonywany przez bohatera filmu przyrównał do swojego aktu twórczego.

To jest przecież ten bolesny eksperyment - wyjaśniał - zabijania rzeczywistości. Ja muszę tworzyć przywileje dla fikcji, a więc muszę świat realny, rzeczywistość, dyskryminować po to, żeby się od niego odbić w wyobraźni. Jest to w gruncie rzeczy piekło mojego doświadczenia twórczego zmetaforyzowane w tej opowieści. Jednocześnie Zabicie ciotki jest to i mój powrót do własnej inicjacji, którą dawno temu i ja przeżywałem[39].

Trzecim rodzajem performansu jest więc odczytanie Zabicia ciotki jako wyreżyserowanego przez Grzegorza Królikiewicza filmu-performansu.

Przyczyny dokonanego przez Jurka rzekomego morderstwa są niejasne, na pytanie księdza „Dlaczego?”[40], odpowiada: „Bo jestem mordercą”[41], Teresie zaś oświadcza: „Nie chcę się wybraniać, cho-

[35] Wypowiedź Grzegorza Królikiewicza na Festiwalu Dwa Brzegi przed projekcją filmu Zabicie ciotki, 2011, <https://www.youtube.com/watch?v=BzP_iZ$2 \mathrm{dhF}_{4}>$, dostęp: 13.12.2021.

[36] Rozmowa Michała Dondzika z Grzegorzem Królikiewiczem, 4 lipca 2017, Łódź, AMD.

[37] Ibidem.
[38] Królikiewicz. Pracuję dla przyszłości: wywiad rzeka..., s. 217.

[39] Nie daję się ponosić fali... - z G. Królikiewiczem rozmawiała M. Brzostowiecka, „Ekran” 1987, nr 48, S. 15.

[40] Cytat z filmu Zabicie ciotki.

[41] Ibidem. 
ciażby dlatego, że wcale nie czuję się winny" [42]. Trudno te pokrętne wyjaśnienia traktować inaczej niż jako próbę mataczenia przed innymi i samym sobą. Nie ulega wątpliwości, że bohater kocha ciotkę, jest to równie oczywiste jak fakt, że Luiza kocha Jurka, dając wyraz swego uczucia rodzicielską opieką, jaką roztacza nad młodzieńcem.

Od osoby kochanej więcej się wymaga - tłumaczył Grzegorz Królikiewicz więcej niż od osoby obojętnej. Od kochanej cioci wymaga się więc, żeby nie gadała, tylko słuchała wierszy Jurka. I żeby była cicho w czasie, kiedy on je jajeczko, bo on w tym czasie właśnie wymyśla wiersz. Osobę kochaną można też zabić - właśnie dlatego, że się od niej wymaga, a ona nie spełnia oczekiwań, rozdrażnia[43].

O ile ciotka traktuje Jurka jak własne dziecko, otaczając go matczyną troskliwością, o tyle stosunek chłopaka do Luizy bliższy jest relacji mąż - żona. Jednak jest to miłość małżeńska niespełniona. Poprzez kulturowe tabu kazirodztwa Jurek może jedynie pożądliwym wzrokiem śledzić nagie piersi ciotki i opierać się próbom (chyba wbrew sobie) ściągnięcia majtek przez Luizę. Niespełniona młodzieńcza żądza daje swój upust w domniemanym zabójstwie opiekunki. Poprzez śmierć ciotka w oczach Jurka zmienia tożsamość, to już nie spokrewniona z nim kobieta, to trup, którego można posiąść. Pieczołowite rozbieranie i krojenie zwłok mają zapewnić Jurkowi niemożliwe dotąd spełnienie. Jednakże władza nad martwym ciałem okazuje się iluzoryczna. Walka ze zwłokami przyjmuje coraz bardziej gwałtowny obrót - Jurek rąbie je siekierą, kroi piłą, mieli w maszynce do mięsa, wysyła w paczkach. Działania te nie służą jedynie ukryciu corpus delicti, ale także pozbyciu się dowodu męskiego niepowodzenia. Dla innych pokawałkowane ciało Luizy to mięso, w czasach kryzysu produkt deficytowy i pożądany. Gdy Jurek usiłuje nadać zapakowany jak baleron ochłap z ciotki, w wychudzonym pracowniku poczty (Krzysztof Kursa[44]) przesyłka wyzwala gwałtowny, zwierzęcy głód. Z kolei z manifestacyjną obojętnością paczkę traktuje otyły pocztowiec, całą uwagę poświęcając pożeraniu pokaźnego kawałka kiełbasy. Zwłokami Luizy zajadają się jej matka i siostra, zwierzęta w ogrodzie zoologicznym oraz dozorca zoo (Leon Niemczyk).

Młodzieńcza potencja i brak spełnienia wyzwala desperackie próby miłosnej realizacji. Jurek nie jest w stanie powstrzymać się od natrętnych skojarzeń, gdy ciotka Emilka przestraszona obecnością zwłok w wannie krzyczy do Jurka: - „Bierz mnie, mówię!”[45] „- W jakim sensie?”[46] - dopytuje chłopak, na co ciotka, pojękując, z błogim wyrazem twarzy, wtula się w siostrzeńca. W tej chwili Jurek nie jest

[42] Ibidem.

[43] Królikiewicz. Pracuję dla przyszłości: wywiad rzeka..., s. 226.

[44] W roli Głodomora obsadzony został Krzysztof Kursa, w którym część widzów Zabicia ciotki mogła rozpoznać wychudzoną postać porucznika z Fortu 13 - poprzedniego filmu Grzegorza Królikiewicza.

[45] Cytat z filmu Zabicie ciotki.

[46] Ibidem. 
już potencjalnym partnerem, a staje się rycerzem, obrońcą uciśnionej niewiasty.

Nową jakością w życiu Jurka jest poznana w pociągu Teresa - ta młoda kobieta ma wynagrodzić wcześniejsze nieudane relacje chłopca, to ona powinna mu zapewnić długo wyczekiwanie spełnienie. „Okres, gdy walka $\mathrm{z}$ trupem zapełniała pustkę mojego życia, już się skończył, trupa zastąpiła Teresa. Dziewczyna nie potrafi zaspokoić i zastąpić wszystkich tęsknot. To byłoby morderstwem miłości”[47] - przyznaje chłopak. Teresa bardzo szybko okazuje się tylko substytutem ciotki. Zawód przychodzi po spędzonej wspólnie nocy, dziewczyna głośno chrapie, co odstręcza Jurka do tego stopnia, że, chcąc uniknąć widoku wybranki, siedzi do niej odwrócony plecami. Zawiedziony fizycznością Teresy („nie jesteś kobieta pruderyjną”[48]) postanawia wyznać jej prawdę o dokonanej przez siebie zbrodni, a tym samym wystawić ją na próbę. Dusza dziewczyny wydaje się Jurkowi równie niezadowalająca jak jej ciało, gdyż po chwili wahania Teresa daje się zainfekować złem. Upodabnia się do Jurka nie tylko psychicznie (biorąc udział w ukryciu zbrodni), ale i fizycznie - w scenie spaceru po lesie bohaterowie są bliźniaczo podobni (mają podobne fryzury, są identycznie ubrani).

Teresa, jako kopia Jurka bez właściwości, bezpowrotnie znika z życia bohatera. Jej miejsce zajmuje Dzika Dziewczyna. Związek z tą postacią zaczyna się od ukąszenia Jurka przez dziewczynę, po raz drugi w podobny sposób sprawdzi ona jego „dzielność”, wgryzając się w dłoń chłopaka. Pierwsze, fizyczne kontakty pary rzutują na ich całą relację. Dzika Dziewczyna jest przedstawicielką świata pierwotnych instynktów, fascynują ją kopulujące i jedzące ludzkie mięso (zwłoki ciotki) tygrysy, lwy oraz jaguary w zoo. Wcześniej Teresa upodobniła się do Jurka; w tym przypadku to bohater zmienia „szatę godową”, zakładając obcisły czarny, skórzany kombinezon ozdobiony czerwonymi wzorami. $\mathrm{W}$ nowym wcieleniu trafia przed klatkę z szympansem. Zwierzę bije mu brawo, po czym zdejmuje maskę przeciwgazową, parodiując nieudaną próbę samobójczą Jurka. Źródło erotycznego zainteresowania małpy oraz znajdującego się po drugiej stronie kraty chłopaka jest takie samo: wzbudzają je karty $\mathrm{z}$ wizerunkami nagich kobiet. Oba samce są w swoich pragnieniach bardzo podobni. O ile jednak u szympansa takie zachowanie jest zgodne $\mathrm{z}$ naturą, o tyle reakcje młodzieńca są świadectwem regresu w zwierzęcość. Kolejnym etapem zezwierzęcenia jest zbliżenie z Dziką Dziewczyną, które odbywa się wewnątrz wielkiej rury. Po raz kolejny Jurek nie zaznaje spełnienia: „To nic, nie przejmuj się, wszystko się uda następnym razem" [49] - pociesza go partnerka, zachęcając do obserwacji „korepetycji”, jakich wraz z tatą udziela „nieudacznikowi”. Naruszenie tabu, jakim jest kazirodczy stosunek, dopełnione jest obrazem kanibalizmu (ojciec Dzikiej Dziewczyny pożera szczątki ciotki).

[47] Cytat z filmu Zabicie ciotki.

[49] Ibidem.

[48] Ibidem. 
Dantejskie sceny, których świadkiem jest Jurek, napawają go przerażeniem. Z chwilą, gdy krzyczy „Nie róbcie tego!”[50], wyrzekając się fantasmagorii swojej wyobraźni, powraca realny świat. Na dworcu pojawia się ukochana ciotka Luiza i wszystko, co złe, okazuje się złudzeniem. Jurek uznaje, że prawdziwie kocha tylko ciocię.

Grzegorz Królikiewicz złączył miłość Jurka do ciotki z uczuciem Andrzeja Bursy do żony Ludwiki[51] - zresztą takiego właśnie imienia bohaterki używają jej matka i ciotka Emilka. Jurek zaś zwraca się do ciotki „Luiza”, co jest nawiązaniem do słynnego poematu Luiza Andrzeja Bursy. Właśnie ten utwór dedykowany Ludwice-Luizie deklamuje Jurek w finale filmu: „To Luiza sprawczynią tej zbrodni i bredni/ Ona szyny i mury zawiązuje w pętlę/ I czas miecza się spełni i piorun się spełni/ Ale piersi Luizy pozostaną piękne"[52].

Wykreowanie niezwykłego świata w Zabiciu ciotki, w którym obiektywna rzeczywistość przenika się z subiektywną, wytworzoną w wyobraźni bohatera, udało się reżyserowi filmu na tyle sugestywnie, że część widzów zagubiła się. Grono krytyków uznało, że Jurek rzeczywiście zabił ciotkę lub że nie wiadomo, czy doszło do zbrodni. W 1985 roku, w okresie dystrybucji filmu w kinach, Mirosław Winiarczyk pisał: „Nie wiem, czy zabójstwo ciotki zaistniało tylko w wyobraźni, czy też zdarzyło się naprawdę. Nie jest to takie ważne”[53]. Wątpliwości wysuwał też Andrzej Kaliszewski, jego zdaniem: „Wprowadza on [film - M.D.] w zdenerwowanie niemożnością znalezienia w pełni jednoznacznej odpowiedzi na pytania: Czy zabił? Czy chciał zabić? Czy mu się wszystko zdawało?”[54]. Wiele lat później podobne emocje targały Tadeuszem Lubelskim: „[...] Widz do końca nie ma pewności, czy ciotka zostaje naprawdę zabita, co jest denerwujące, ale tym ostrzej wyraża nastrój”[55] - podkreślał w Historii kina polskiego. Warto przytoczyć także przykład współczesnej recepcji filmu przez zagranicznego znawcę, austriackiego profesora filmoznawstwa Marcusa Stigleggera. Według niego w Zabiciu ciotki „[...] reżyser tworzy tu asocjacyjną panoramę snów lub urojeń młodego mężczyzny, który wyjawia księdzu, że zamordował ciotkę. Kiedy ta pojawia się żywa i demaskuje kłamstwo, postanawia dokonać tego czynu"[56]. Do kwestii, czy zbrodnia wydarzyła się naprawdę, reżyser Grzegorz Królikiewicz odwoływał się

[50] Ibidem.

[51] 26 lutego 1952 roku Andrzej Bursa wziął ślub z Ludwiką Szemioth, wówczas studentką krakowskiej Akademii Sztuk Pięknych. Zob. E. Dunaj Kozakow, op.cit., s. 83 .

[52] A. Bursa, Pętla architektury, fragment poematu Luiza, [w:] Andrzej Bursa, Utwory wierszem i proza, wybrał, opracował i wstępem poprzedził Stanisław Stanuch, Kraków 1982, s. 97.

[53] M. Winiarczyk, Psychoza po polsku, „Ekran” 1985, nr 40, s. 17. Wcześniej redaktor „Ekranu” napisał: „Do końca nie wiemy, czy zabójstwo ciotki jest faktem rzeczywistym, czy zaistniało tylko w wyobraźni bohatera”. M. Winiarczyk, Na co do kina - Zabicie z ciotki, „Ekran” 1985, nr 37, s. 17.

[54] A. Kaliszewski, Bursa żywy, „Dziennik Polski” 1985 , nr 271, s. 3.

[55] T. Lubelski, Historia kina polskiego. Twórcy, filmy, konteksty, Chorzów 2008, s. 486.

[56] M. Stiglegger, „Brudne obrazy”. Okrucieństwo u Żuławskiego i Królikiewicza, [w:] W poszukiwaniu polskiej nowej fali, red. A. Gwóźdź, M. Wach, Warszawa - Kraków 2017, s. 237. 
wielokrotnie. Podczas kolaudacji filmu powiedział: „Proszę Państwa, jestem w kłopotliwej sytuacji, bo wysłuchałem jakichś opinii zastępczych, jakichś porównań, chociaż zapewniam, że nikogo nie zabiłem i tego też nie zrobił mój bohater"[57]. W wywiadzie-rzece wyjaśniał: „Ale o to właśnie chodzi [...], żeby doprowadzić widza do absolutnej iluzji [...]. I potem jest odkrycie kart. Przyjeżdża ciotka [...], a Jurek zaczyna koziołkować z radości, że ciotka żyje, a on nie zgrzeszył”[58]. Z kolei w trakcie monograficznego przeglądu swoich filmów zapewniał publiczność: „Jak pamiętacie państwo zakończenie tego filmu, ciocia wyjechała tylko na wczasy" [59].

Przypomnijmy więc raz jeszcze, że ciotka Luiza wraca $z$ wakacji żywa, cała i zdrowa! Zanim jednak to nastąpi, widzowi sugerowane jest, że zbrodnia wydarzyła się naprawdę. Morderstwo jest przestępstwem ściganym zgodnie z prawem. O tym, że zbrodnia musi pociągnąć za sobą karę, wie także Jurek, stąd zaraz po dokonaniu domniemanego zabójstwa usiłuje zatrzeć ślady. W filmie ukazane jest prawo, które funkcjonuje w specyficzny sposób. Jurek, jako student wydziału prawa, jest świadkiem, jak profesor myli roczniki i niesprawiedliwie karze studentów drugiego (zamiast trzeciego) roku. Gdy wykładowca dowiaduje się o pomyłce, nie robi nic, aby zadośćuczynić niesprawiedliwie osądzonej młodzieży. Komentarzem do tak pojętej równości wobec „ślepego prawa” jest krótka scena - Jurkowi znajomi ze studiów zasłaniają oczy, parodiując w ten sposób postać Temidy. Nie mniej dziwnym przypadkiem jest oficer dyżurny milicji (Wiesław Gołas). O dziwo, podobnie jak Jurek jest on studentem prawa, który w trakcie służby na komisariacie uczy się kodeksu Hammurabiego, szczerze podziwiając jego autora. W telewizji słychać z kolei o procesie sądowym, w którym w wziął udział prokurator i obrońca w jednej osobie. Swoistym podsumowaniem ułomności prawa jest skierowane do Teresy wyznanie Jurka: „Wyłupujemy sobie oczy, łamiemy ręce, wyrywamy serca, chowamy w domach trupy - to wszystko nie zwalnia mnie od prawnej odpowiedzialności za mój czyn, tylko widzisz, jakoś innej sprawiedliwości nie zaznałem w swoim życiu, a omylność tej jest nam dostatecznie znana"[60]. Nieskuteczność prawa karnego nie zwalnia bohatera z zakodowanego wewnętrznego poczucia, że obowiązuje go jeszcze prawo moralne.

Świat w Zabiciu ciotki Grzegorza Królikiewicza to rzeczywistość nasycona symbolami chrześcijaństwa: Jurek nosi na szyi krzyż, na cmentarzu widoczna jest mozaika z Jezusem Chrystusem, ciotka Teresy jest prawdopodobnie zakonnicą, ciotka Emilka żegna się znakiem krzyża, Mistyk (Gustaw Holoubek) wita Jurka słowami „Niech będzie pochwalony Jezus Chrystus”[61], a chłopak odpowiada „Na wieki

[57] Stenogram z posiedzenia Komisji Kolaudacyjnej Filmów Fabularnych w dniu 1 października 1984. Na porządku dziennym omówienie filmu Zabicie ciotki, reż. Grzegorz Królikiewicz, sygn. A-344, poz. 378, k. 12, AFINA.
[58] Królikiewicz. Pracuję dla przyszłości: wywiad rzeka..., s. 218.

[59] Lekcja kina - Grzegorz Królikiewicz, 5 Festiwal Sztuki i Filmu Dwa Brzegi, 2011, AFINA.

[60] Cytat pochodzi z filmu Zabicie ciotki.

[61] Ibidem. 
wieków, amen"[62]. Istotną rolę odgrywa chrześcijańska spowiedź, to najpierw księdzu Jurek wyznaje swoją winę, a dopiero później Teresie (cytując formułkę spowiedzi: „Więcej grzechów nie pamiętam”[63]). O to kiedy chłopak był u spowiedzi, dopytuje się także ciotka.

W chrześcijaństwie, poza wyznaniem grzechów w konfesjonale przed kapłanem, akt pokuty i spowiedź powszechna następują w trakcie każdej mszy - „Spowiadam się Bogu wszechmogącemu i wam, bracia i siostry, że bardzo zgrzeszyłem myślą, mową, uczynkiem i zaniedbaniem. Moja wina, moja wina, moja bardzo wielka wina”. Właśnie odczucie, że myśl o zabiciu ciotki jest grzechem, powoduje, że Jurek rozpoczyna grę, w której może ponieść konsekwencje zarówno prawne, moralne, jak i duchowe. Fakt, że zabija ciotkę Luizę w myślach, nie stanowi o tym, że jego czyn jest mniej moralnie szkodliwy niż realne zabójstwo. Jurkiem identyfikującym się zbrodnią powoduje strach przed karą fizyczną (ewentualnym więzieniem i karą śmierci) oraz degradacją duchową, a nawet piekłem. Dlatego bohater wielokrotnie stara się wyznać prawdę o dokonanej zbrodni. Po prowokacji, jaką była nieudana spowiedź w kościele, Jurek szuka ukojenia w świeckich wyznaniach. Przybierają one formę bełkotliwych monologów w czasie pijatyki z kolegami, czy też krzyków o zbrodni w trakcie jazdy karawanem, jak i poważnego, samoświadomego wyjawienia grzechu przed Teresą. Tajemniczą postacią, z którą bohater rozmawia o swoim czynie, jest Mistyk. Po raz pierwszy pojawia się on w filmie podczas spowiedzi Jurka. Mężczyzna wrzuca monetę do figurki aniołka, a następnie leży przed nią krzyżem[64]. Postać staruszka i aniołka odnajdziemy też w jednym z wierszy Andrzeja Bursy: „Gdy ci się wszystko znudzi/ spraw sobie aniołka i staruszka/ gra się tak:/ podstawiasz staruszkowi nogę że wyrżnie mordą o bruk/ aniołek spuszcza główkę/ dasz staruszkowi 5 groszy/ aniołek podnosi główkę [...]/ wylejesz staruszkowi na głowę nocnik/ aniołek spuszcza główkę/ powiesz staruszkowi „szczęść Boże”/ aniołek podnosi główkę/ i tak dalej"[65]. Rozważania na temat dobra i zła mają swoją kontynuację w więziennej celi, w chwili drugiego spotkania Jurka z Mistykiem (trafił on do celi za kradzież złotej ręki z kościoła Kapucynów). Rozmowa, której tematem jest uniknięcie przez świętokradcę konsekwencji karnych, ma też aspekt moralny. Zdaniem Mistyka istnienie dobra jest równoznaczne z działalnością zła. „Skoro Bóg ustanowił świętość, ustanowił również świętokradców. Skoro u fundamentów religii leży legenda o morderstwie, muszą istnieć mordercy"[66] - przekonuje. Świętokradca jest więc samozwańczym kapłanem, który nie tylko nie potępia Jurka za dokonane morderstwo, lecz daje mu rozgrzeszenie, ze śmiertelnego grzechu czyniąc zasługę.

[62] Ibidem.

[63] Ibidem.

[64] W książce Andrzeja Bursy świętokradca wykrada znajdujące się wewnątrz anioła-skarbonki pieniądze.
Zob. A. Bursa, Zabicie ciotki..., s. 53 .

[65] A. Bursa, Z zabaw i gier dziecięcych, [w:] idem,

Utwory wierszem i proza..., s. 117.

[66] Cytat pochodzi z filmu Zabicie ciotki. 
Ostatnią szansą na moralne ocalenie Jurka jest, jak się zdaje, niewinna i dobra Teresa. Chłopak nie tylko wyznaje jej swój grzech, ale epatuje wybrankę widokiem ukrytych w wannie zwłok. Pomimo tych demonstracji dziewczyna, po krótkiej chwili moralnych rozterek, przyłącza się do mordercy. Para wybiera się na sielski spacer po lesie, czerpiąc perwersyjną przyjemność z rozważań, jaka część ciotki jest w niesionej przez nich paczce. Truchło ciotki nie są już czymś wstydliwym, Teresa wydaje się traktować je wręcz jako swoisty owoc ich relacji. Idylli nie psuje nawet pojawienie się dziwnej postaci, będącej prawdopodobnie współczesnym wyobrażeniem strażnika Edenu - archanioła Michała z gorejącym mieczem. „Zostaliśmy wypędzeni z raju, trzeba się będzie uczyć języków obcych"[67] - zauważa Jurek, po czym zaczyna wraz z Teresą deklamować wiersz:

Twój ojciec pali fajkę. Yes, my father smokes the pipe. Powtórz to zdanie, otworzy ci ono okno na świat. Gdy będziesz siedział na Broadwayu w barze piękniejszym niż oczy szatana, wtedy spytają cię niezawodnie, czy twój ojciec pali fajkę, wtedy odpowiesz: Yes, my father smokes the pipe[68].

Ćwiczenie języka angielskiego jako reakcja na wygnanie z raju, ale też przypomnienie biblijnego pomieszania języków, jest oczywistym żartem podkreślającym lekceważący stosunek pary do zbrodni i jej kon-

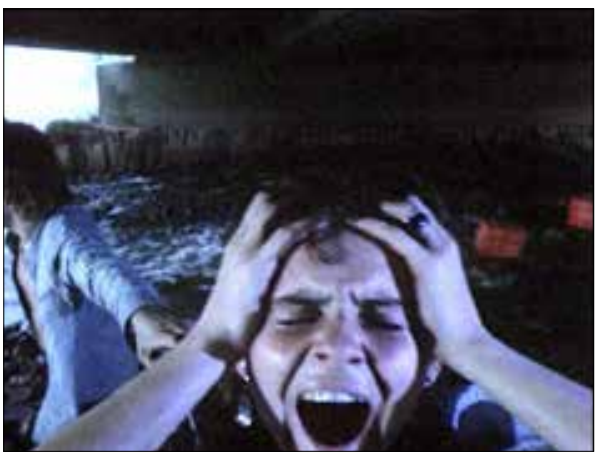
sekwencji. Teresa jest nawet wdzięczna chłopakowi za „wciągnięcie w taką niezwykłą sprawę" [69], chce służyć Jurkowi-mordercy. Fascynacja złem kończy się zgodnie z wcześniejszym ostrzeżeniem chłopaka: „Mówię delikatnie, żebyś nie zwariowała”[70]. Teresa wpada w amok, nie mogąc uwolnić się z rąk trzymającego ją na uwięzi Jurka. Ciężar spadającej na nią kary podkreśla ustylizowanie ujęcia na cytat z obrazu Krzyk Edvarda Muncha. Scena spaceru po lesie i topienie paczek jest metaforą grzechu pierworodnego popełnionego przez pierwszych ludzi oraz grzechów, których dopuszczają się współcześni[71].

Il. 5. Szaleństwo Teresy, czyli filmowy cytat z Krzy$k u$ Edvarda Muncha
Przestrogę przed karą, jaką może być piekło tworzone przez chłopaka w swoim umyśle, przedstawiają Jurkowi ksiądz w trakcie spowiedzi oraz ciotka. Oboje powtarzają nieomal te same słowa:

Strzeż się, bo ty zakochałeś [tu zaczyna swoją wypowiedź ciotka] się w swojej wyobraźni. A najgorsze [najstraszniejsze - ciotka] piekło to jest właśnie takie, że myśl o zbrodni toczy się w tobie jak koło i trwa w powtórzeniach,
[67] Ibidem.

[68] Cytat pochodzi z filmu Zabicie ciotki. Por.

A. Bursa, Języki obce, [w:] idem, Utwory wierszem i proza..., s. 72.

[69] Cytat pochodzi z filmu Zabicie ciotki.

[70] Ibidem.
[71] W Zabiciu ciotki przedstawiona jest też parodystyczna wersja dzisiejszego „edenu”. W trakcie libacji alkoholowej, w której uczestniczy Jurek, jeden z kolegów przedstawia wyjazd na Zachód jako swoiście rozumiany ziemski raj: „Śniadanie stawiają i setkę, obiad stawiają i setkę, kolację stawiają i pół litra i całą noc się pierdolisz". Cytat pochodzi z filmu Zabicie ciotki. 
i chociaż potem sumienie twoje patrzy na to w udręce, to wola twoja nie może już zatrzymać ruchu powtórzeń. To jest właśnie twoje piekło. [...] Wielcy ludzie to ci, którzy zwyciężają piekło własnej wyobraźni[72].

Jurek, dla którego eksperyment z wyobraźnią stopniowo staje się koszmarem, na pewnym etapie nie jest w stanie zatrzymać eskalacji swoich myśli. Kresem niebezpiecznej zabawy jest regres w zwierzęcość i dotknięcie tabu kazirodztwa. Bohater tak daleko zabrnął w swoich fantasmagoriach, że nawet gdy ciotka rzeczywiście wraca $\mathrm{z}$ wakacji, nie może uwierzyć w jej powrót.

W Zabiciu ciotki bohater ponosi karę za zbrodnię w myślach tak samo, jakby popełnił prawdziwe morderstwo. Chciałoby się zapytać: jaka jest moralna odpowiedzialność reżysera za stworzenie filmu o zbrodni? Czy realizacja Zabicia ciotki może być grzechem? W chwili, w której Jurek zamierzył się młotkiem na ciotkę Luizę, w jego umyśle zrodziła się mordercza myśl i to ona, zdaniem twórcy filmu, powinna być penalizowana. Choć niemożliwe jest zbadanie intencji reżysera $\mathrm{w}$ momencie podjęcia decyzji o realizacji dzieła, niewątpliwie zasadniczym tematem Zabicia ciotki są rozważania o mordzie i jego konsekwencjach. Gdyby Grzegorz Królikiewicz zrealizował Zabicie ciotki kierowany zbrodniczą intencją, planując zainfekowanie umysłów widzów agresją wobec najbliższych, można by mówić o grzechu, jednak filmowa opowieść o zbrodni okazuje się moralitetem. Zabicie ciotki jest zatem współczesną przypowieścią o zbrodni, pokucie i nawróceniu. W dydaktycznym zakończeniu filmu, po ekspiacji Jurka, zabita w myślach ciotka wraca $z$ wakacji. Wszystko wskazuje na to, że młodzieniec wraz z ukochaną ciocią będą żyli w symbiotycznym związku (albo jest to jeszcze jeden $z$,powrotów” tak charakterystycznych dla narracyjnej konstrukcji fabuły).

Aby w pełni ukazać moralizatorski wymiar Zabicia ciotki, warto rozkodować ostatnie ujęcie filmu. Ukazano w nim ułożony na czerwonym suknie wykonany ze stali szewski młotek. Jest to „pokazowy" egzemplarz, podobny do tego, w jaki zamienił się „zwykły” młotek, którym Jurek miał na początku filmu zabić ciotkę. Młotek - banalny i powszechnie dostępny przedmiot - w filmie staje się narzędziem zbrodni oraz metaforą grzechu. Młotki pojawiają się $\mathrm{w}$ filmie wielokrotnie, jeden $\mathrm{z}$ nich wisi nawet przy habicie franciszkanina. Wszystkie nawiązują do tego ukazanego w ostatnim ujęciu „archetypu”. Zdaniem Grzegorza Królikiewicza ma on podkreślać, że „zawsze istnieje możliwość spełnienia zbrodni przez każdego z nas”[73]. Ukazany w ostatnim ujęciu młotek to ostrzeżenie, którego żaden z wi-

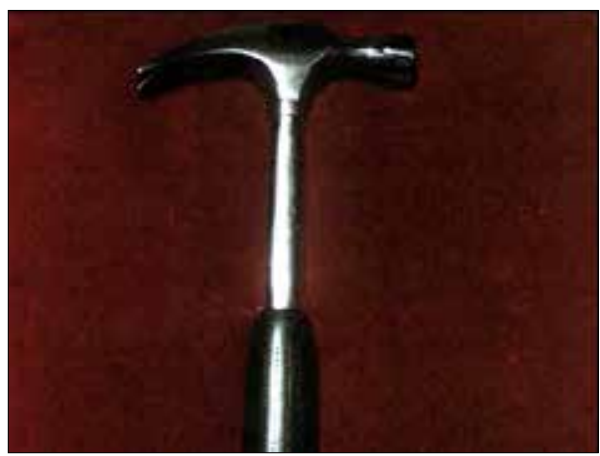
dzów Zabicia ciotki nie powinien zlekceważyć.

[72] Cytat pochodzi z filmu Zabicie ciotki.
[73] Królikiewicz. Pracuję dla przyszłości: wywiad rzeka..., s. 218.
Il. 6. Młotek jako metafora grzechu 
B I B L I O G R A F I A

[74] „Trzy miesiące żyłem na wolności, urodziłem się w czerwcu 1939 roku i potem już całe moje życie przebiegło $\mathrm{w}$ niewoli. Jestem niewolnikiem, najpierw niemieckim, a potem rosyjskim i żyję w niewoli” - podkreślał Grzegorz Królikiewicz. Zob. Z wizyta u muz - z Grzegorzem Królikiewiczem rozmawiał Cz.A. Czapliński, „Kariera” 1993, nr 3, s. 31. [75] A. Bursa, Zabicie ciotki..., s. 5. 
Stiglegger M., „Brudne obrazy”. Okrucieństwo u Żuławskiego i Królikiewicza, [w:] W poszukiwaniu polskiej nowej fali, red. A. Gwóźdź, M. Wach, Warszawa Kraków 2017

Warpechowski Z., Konserwatyzm awangardowy, Kraków 2014

Warpechowski Z., Podnośnik, Jerozolima - Rzym - Sandomierz 2001

Winiarczyk M., Na co do kina - „Zabicie z ciotki”, „Ekran” 1985, nr 37

Winiarczyk M., Psychoza po polsku, „Ekran” 1985, nr 40

Wypowiedź Grzegorza Królikiewicza na Festiwalu Dwa Brzegi przed projekcją filmu Zabicie ciotki, 2011, https://www.youtube.com/watch?v=BzP_iZ2dhF4, dostęp: 13.12.2021

Z wizyta u muz - z Grzegorzem Królikiewiczem rozmawiał Cz.A. Czapliński, „Kariera” 1993, nr 3 